\title{
The Selective Toxicity of Antimicrobial Nitroheterocyclic Drugs
}

\author{
By D. I. EDWARDS, M. DYE AND HILARY CARNE \\ Department of Applied Biology, North East London Polytechnic, \\ Romford Road, Stratford, London, E. I5
}

(Received 17 October 1972 ; revised 4 December 1972)

\begin{abstract}
SUMMAR Y
Three antimicrobial nitroimidazole drugs (metronidazole, dimetridazole, and tinidazole) inhibit a range of clostridia and the protozoan Trichomonas vaginalis; they have an identical site and mode of action as specific electron acceptors from the pyruvate phosphoroclastic reaction. Analogues of the drugs are compared and the structural requirements for activity explained. The nitrofuran (nitrofurazone) probably has a different mechanism of action.
\end{abstract}

\section{INTRODUCTION}

The basis for the selective activity of many antimicrobial drugs is an interference with molecular mechanisms peculiar to particular taxonomic groups, e.g. those agents which exploit structural and biosynthetic differences between prokaryotic and eukaryotic organisms, or, more specifically, those drugs whose action depends upon the presence or absence of a biochemical mechanism unique to a particular group within a major taxon. Generally, the 'spectrum of activity' of an antimicrobial drug reflects the taxonomic boundary beyond which its activity is minimal. Such drugs are clearly delineated from disinfectants or antiseptics which have no taxonomic specificity and are not selectively toxic within the organism. In this respect a number of nitroheterocyclic drugs (5-nitrothiazoles, 5-nitrofurans, 5-nitroimidazoles) are unusual in that their action is selectively toxic, but their spectrum of activity transcends major taxonomic boundaries.

Metronidazole (I- $\beta$-hydroxyethyl-2-methyl-5-nitroimidazole; May \& Baker Ltd, Dagenham, Essex) is active against a wide range of Gram-positive and Gram-negative bacteria (Fuzi \& Czukas, I970), many protozoa (Cosar \& Joulou, I959; Lucas, I96I; Felix \& Ouryoux, I962; Powell, McLeod, Wilmot \& Elsdon-Drew, 1966), and even a few nematode worms. It is the drug of choice at present against trichomonal vaginitis, all forms of amoebiasis caused by Entamoeba histolytica, and Vincent's angina - an acute ulcerative condition of the mouth caused by anaerobic bacteria. Metronidazole, like other nitroimidazoles, is active only against anaerobic organisms. Its remarkable activity against gas gangrene in mice (Freeman, McFadzean \& Whelan, 1968) in which it is 20 to 50 times more effective than penicillin or tetracycline, and its recent use against gas gangrene in man (Thornley \& Edwards, 1973), further indicates its clinical effectiveness against anaerobes.

Tinidazole (ethyl-I-[2-(2-methyl-5-nitroimidazolyl)-ethyl] sulphone; Pfizer Ltd, Sandwich, Kent), is more active than metronidazole in vitro against Trichomonas vaginalis, but not in vivo (Miller, Howes \& English, 1970). Its structural similarity to metronidazole may result in a similar spectrum of activity.

Dimetridazole (1,2-dimethyl-5-nitroimidazole; May \& Baker Ltd), is used to treat infections of the anaerobe Histomonas melagreadis in poultry. 
<smiles>Cc1ncc([N+](=O)[O-])n1CCO</smiles>

Metronidazole (1- $\beta$-hydroxyethyl-2-methyl 5-nitroimidazole)<smiles>O=[N+]([O-])c1cnn(CCO)c1</smiles>

M \& B 4998

(1- $\beta$-hydroxyethyl-4-nitropyrazole)<smiles>Cc1ncc([N+](=O)[O-])n1C</smiles>

Dimetridazole<smiles>Cc1nc([N+](=O)[O-])cn1C</smiles>

8609 RP

(1,2-dimethyl-5-nitroimidazole)<smiles>CCOS(=O)(=O)CCn1c([N+](=O)[O-])cnc1C</smiles>

Tinidazole (ethyl-1-[2-(2-methyl-5-nitroimidazolyl)-ethyl]sulphone)<smiles>NC(=O)N/N=C/c1ccc([N+](=O)[O-])o1</smiles>

Nitrofurazone

(5-nitrofurfuraldehyde semicarbazone)

Fig. I. Structure of compounds used in this study.

Nitrofurazone and nitrofurans in general are not selectively toxic to anaerobes, having been used to combat aerobic infections (Paul \& Paul, I964). However, the group shows enhanced activity against anaerobes, and aerobic mutants resistant to nitrofurans remain susceptible under anaerobic conditions (Asnis, Cohen \& Gots, I952).

We now report an investigation into the effects of metronidazole, tinidazole, dimetridazole, nitrofurazone and two analogues - the 4-nitro analogue of dimetridazole (8609 RP), and the pyrazole derivate of metronidazole (M \& B 4998) (see Fig. I for structure) - on a range of clostridia and Trichomonas vaginalis, with a view to elucidating the structural requirements, and site and mechanism of action of these drugs.

\section{METHODS}

Organisms. Clostridium welchii type A (NCIB 6784), C. bifermentans (NCIB 506), C. sporogenes (NCTC 532), C. histolyticum (NCIB 503), C. tetanomorphum (NCTC 2909), C. tertium (NCIB 9363), C. butyricum (NCIB 7423) and C.pasteurianum (ATCC60I3) were obtained through the courtesy of Dr G. C. Mead, Food Research Institute, Norwich, and maintained on Oxoid (Oxoid Division of Oxo Ltd, London) Reinforced Clostridial Medium (RCM). Trichomonas vaginalis strain I 295, was maintained at $37^{\circ} \mathrm{C}$ on Bushby's medium (Bushby \& Copp, I955) modified as previously described (Edwards \& Mathison, I970). 
Table I. M.i.c. values for six nitroheterocyclic compounds against eight species of clostridia and Trichomonas vaginalis

\begin{tabular}{|c|c|c|c|c|c|c|}
\hline & $\begin{array}{c}\text { Metro- } \\
\text { nidazole }\end{array}$ & $\begin{array}{l}\text { Tini- } \\
\text { dazole }\end{array}$ & $\begin{array}{c}\text { Dimetri- } \\
\text { dazole }\end{array}$ & $\begin{array}{r}\text { M \& B } \\
4998\end{array}$ & $\begin{array}{c}8609 \\
\text { RP }\end{array}$ & $\begin{array}{l}\text { Nitro- } \\
\text { furazone }\end{array}$ \\
\hline Clostridium welchii & $1 \cdot 6$ & $6 \cdot 4$ & $3 \cdot 2$ & $>100$ & $>100$ & 25 \\
\hline C. tertium & $1 \cdot 6$ & $3 \cdot 2$ & $3 \cdot 2$ & $>100$ & 25 & $6 \cdot 4$ \\
\hline C. bifermentans & $1 \cdot 6$ & $3 \cdot 2$ & $I \cdot 6$ & $>100$ & 25 & 50 \\
\hline C. pasteurianum & 0.8 & $1 \cdot 6$ & 0.4 & $50-100$ & 12 & 25 \\
\hline C. sporogenes & $\mathrm{I} \cdot 6$ & $6 \cdot 4$ & $1 \cdot 6$ & $>100$ & I 2 & $12 \cdot 8$ \\
\hline C. histolyticum & $3 \cdot 2$ & 25 & $I \cdot 6$ & $>100$ & 50 & 50 \\
\hline C. tetanomorphum & 0.8 & $3 \cdot 2$ & 0.4 & $>100$ & 25 & 25 \\
\hline C. butyricum & $1 \cdot 6$ & 0.8 & 0.2 & $>100$ & 25 & $6 \cdot 4$ \\
\hline Trichominas vaginalis & $1 \cdot 2$ & $1 \cdot 0$ & $\mathrm{I} \cdot 5$ & $5 \cdot 0$ & $>50$ & $>50$ \\
\hline
\end{tabular}

All values are given in $\mu \mathrm{g} / \mathrm{ml}$.

Compounds. Metronidazole, tinidazole, dimetridazole, I- $\beta$-hydroxyethyl-4-nitropyrazole and I,2-dimethyl-4-nitroimidazole were dissolved in distilled water, or $0.85 \%(\mathrm{w} / \mathrm{v})$ sodium chloride solution, and sterilized by filtration. Nitrofurazone was dissolved in a minimum of dimethylformamide (DMF) and the solution made up to volume with distilled water or $0.85 \%(w / v)$ sodium chloride solution. The final concentration of DMF, which was about $0.02 \%(\mathrm{w} / \mathrm{v})$, had no effect on the growth of any of the organisms.

Viable counts. Growth and viability of the clostridia were measured on RCM agar using the method of Miles \& Misra ( 1938 ), incubating at $37^{\circ} \mathrm{C}$ in anaerobic jars containing hydrogen and carbon dioxide (GasPak; Baltimore Biological Laboratories). Trichomonas vaginalis was counted directly in a Neubauer Cell Chamber, viability being assessed by counting those cells showing movement of both undulating membrane and anterior flagella (Edwards \& Mathison, 1970).

Manometric measurements. These were carried out using conventional techniques (Umbreit, Burris \& Stauffer, 1964). Hydrogen and carbon dioxide evolution were measured by means of paired flasks each containing $2.0 \mathrm{ml}$ cell suspension, and with $0.2 \mathrm{ml}, 20 \%(\mathrm{w} / \mathrm{v})$ potassium hydroxide solution in the central well of one. Carbon dioxide gas was determined by difference. The gas phase was argon, shaking rate 70 strokes $/ \mathrm{min}$, and incubation temperature $37^{\circ} \mathrm{C}$.

pH measurements. A Pye $\mathrm{pH}$ meter and Servoscribe recorder were used.

Spectrophotometry. Metronidazole was reduced in an anaerobic cuvette in which a continuous stream of argon was bubbled outside the light path (I cm). Extinctions were measured using Unicam SP-800 spectrophotometer.

Polarography. An Atlas Tast Polarograph with dropping mercury cathode and saturated calomel reference anode was used. Compounds were dissolved at $0.1 \mathrm{~mm}$ in McIlvaine's buffer (sodium citrate/sodium phosphate, $0 \cdot 16 \mathrm{M}$ ), $\mathrm{pH} 6 \cdot 0$, to which was added Triton X-Ioo $(0.00 \mathrm{I} \%, \mathrm{v} / \mathrm{v}$, final concentration) to suppress wave maxima phenomena.

\section{RESULTS}

Table I shows the minimum inhibitory concentrations (m.i.c.) of six compounds against eight species of clostridia and Trichomonas vaginalis. The 5-nitroimidazoles, metronidazole, tinidazole and dimetridazole were the most active against both the bacteria and the protozoan, the 4-nitroimidazole (8609 RP) and the nitrofuran (nitrofurazone) were up to 50 times less active, the latter being inactive against $T$. vaginalis; the 5 -nitropyrazole (M \& B 4998) 


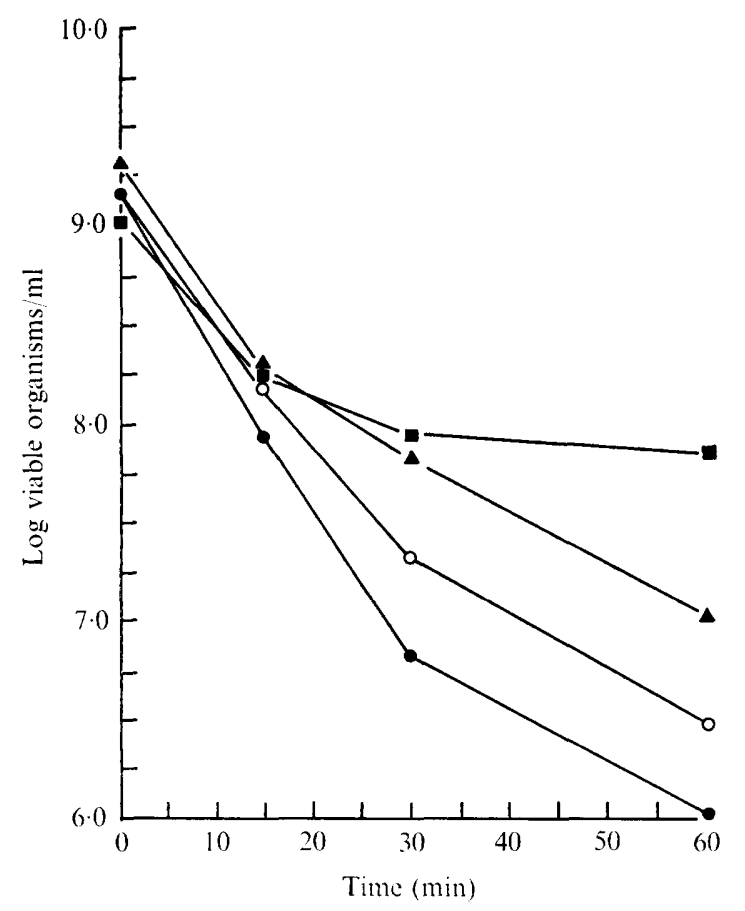

Fig. 2. The bactericidal action of nitroheterocyclic compounds against Clostridium welchii. All compounds were added at o min to give a final concentration of $100 \mu \mathrm{g} / \mathrm{ml}$. Samples were removed anaerobically and dilutions plated on RCM agar. Incubation of plates were carried out in anaerobic jars at $37^{\circ} \mathrm{C}$, for $48 \mathrm{~h}$, and growth assessed by the Miles \& Misra (1938) method after $48 \mathrm{~h}$.

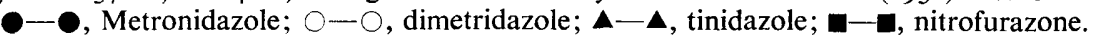

was inactive against the clostridia (m.i.c. 50 to $100 \mu \mathrm{g} / \mathrm{ml}$ ) while showing some activity against the protozoan $(5.0 \mu \mathrm{g} / \mathrm{ml})$.

Rate of kill (death rate) and the effect of the 5-nitroimidazoles on the patterns of gas evolution were examined using Clostridium welchii and Trichomonas vaginalis. Clostridium welchii was chosen because of its typical susceptibility to the nitroimidazoles and because it does not readily sporulate in ordinary media, so facilitating viable count determinations. Further, since it is one of the least oxygen-sensitive species of Clostridium it is easier to work with than the stricter anaerobes.

The bacteriocidal action of the 5-nitroimidazoles against Clostridium welchii is shown in Fig. 2. Similar results were obtained for the action of these drugs on Trichomonas vaginalis.

Edwards \& Mathison (1970) have shown that metronidazole specifically inhibits the evolution of hydrogen gas in Trichomonas vaginalis before that of carbon dioxide. This action is a consequence of the ability of the drug to accept electrons from an electron transfer protein similar to ferredoxin. Metronidazole is capable of accepting electrons from reduced spinach ferredoxin (Edwards \& Schoolar, 1971; Edwards \& Mathison, 1973), and if 5-nitroimidazoles have a similar mode of action, they should inhibit $\mathrm{H}_{2}$ evolution in clostridia which contain a ferredoxin-dependent phosphoroclastic reaction responsible for $\mathrm{H}_{2}$ formation. The effects of the 5-nitroimidazoles on $\mathrm{H}_{2}$ and $\mathrm{CO}_{2}$ evolution in Clostridium welchii and $T$. vaginalis were therefore examined.

The action of metronidazole, dimetridazole and tinidazole on the gas evolution of Clostridium welchii is shown in Fig. 3, 4 and 5 respectively. The action of the 5 -nitrofuran, 

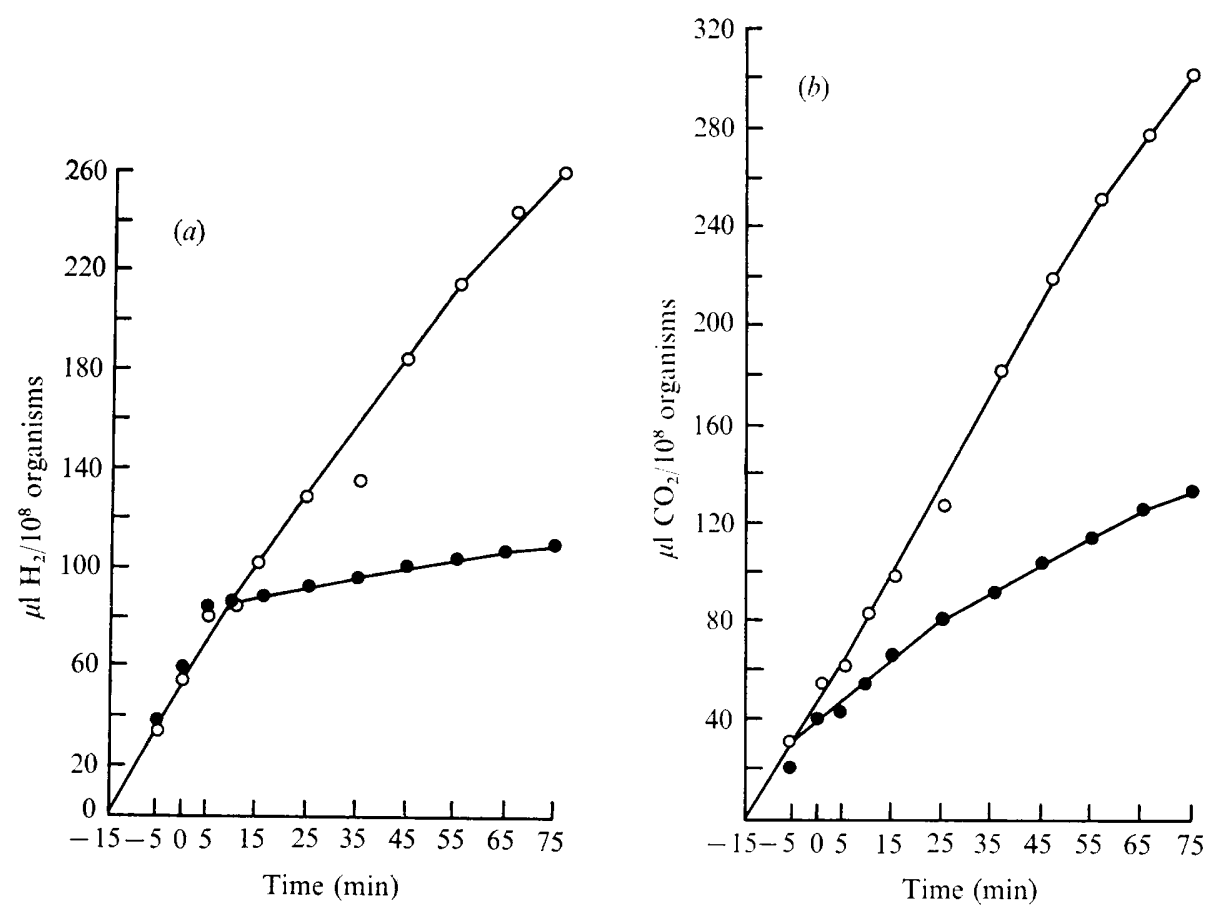

Fig. 3. The effect of metronidazole on gas evolution by Clostridium welchii. (a) Effect on $\mathrm{H}_{2}$ evolution. The main flasks contained $2 \mathrm{ml}$ of a $10^{8} / \mathrm{ml}$ organism suspension in $\mathrm{RCM}$, the side arm contained either metronidazole in RCM to give a final concentration of $100 \mu \mathrm{g} / \mathrm{ml}$, or RCM only. Drug was added at $\mathrm{O}$ min. $\mathrm{O}-\mathrm{O}, \mathrm{H}_{2}$ evolution in absence of drug; $-\mathrm{O}, \mathrm{H}_{2}$ evolution in presence of drug. (b) Effect on $\mathrm{CO}_{2}$ evolution. Details as for $(a)$.
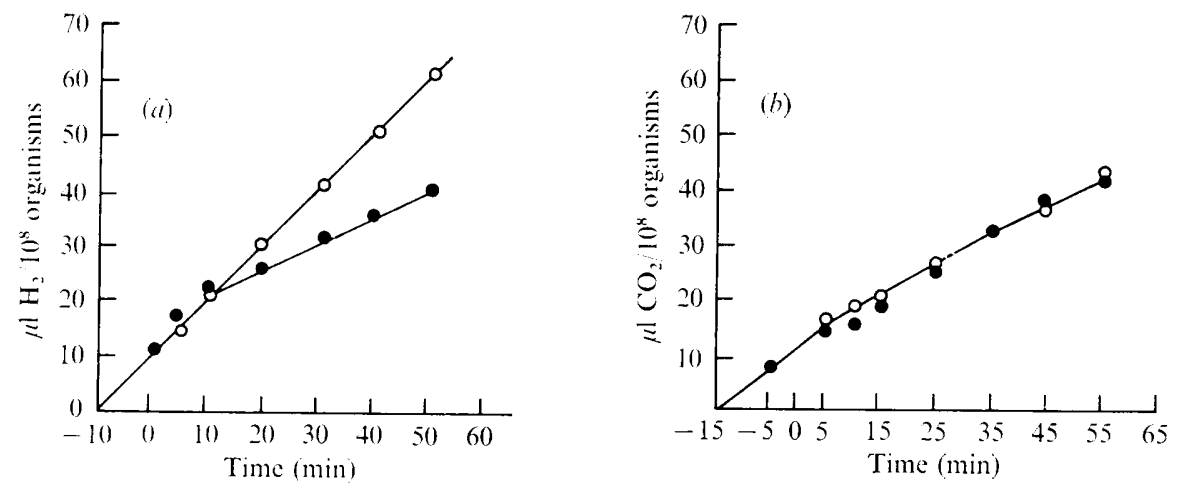

Fig. 4. The effect of dimetridazole on gas evolution by Clostridium welchii. (a) Effect on $\mathrm{H}_{2}$ evolution, data as for Fig. $3(a)$ except that the side arm contained dimetridazole to give a final concentration of $100 \mu \mathrm{g} / \mathrm{ml}$. Drug was added at $0 \mathrm{~min}$. $\mathrm{O}-\mathrm{O}, \mathrm{H}_{2}$ evolution in absence of dimetridazole; -, $\mathrm{H}_{2}$ evolution in presence of dimetridazole. (b) Effect on $\mathrm{CO}_{2}$ evolution. Details as for $(a)$. 

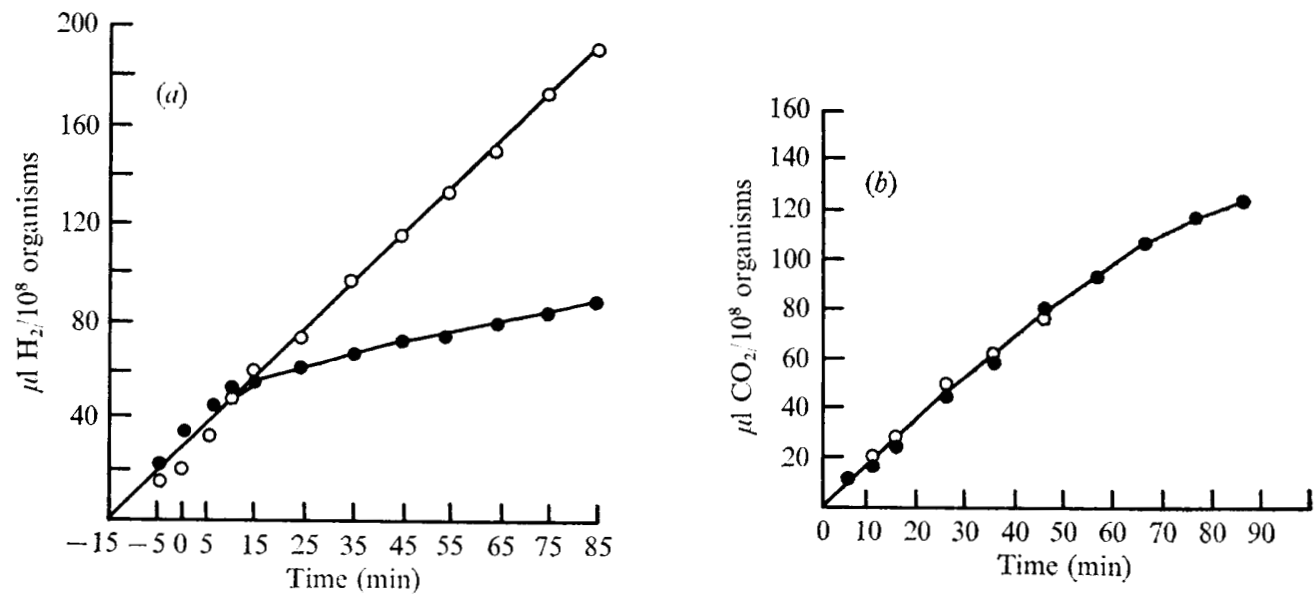

Fig. 5. The effect of tinidazole on gas evolution by Clostridium welchii. (a) Effect on $\mathrm{H}_{2}$ evolution. Details as for Fig. $3(a)$ except that the side arm contained tinidazole to give a final concentration of $100 \mu \mathrm{g} / \mathrm{ml}$. Drug was added at o min. $\mathrm{O}-\mathrm{O}, \mathrm{H}_{2}$ evolution in absence of drug; $-\mathrm{O}, \mathrm{H}_{2}$ evolution in presence of drug. (b) Effect on $\mathrm{CO}_{2}$ evolution. Details as for (a).
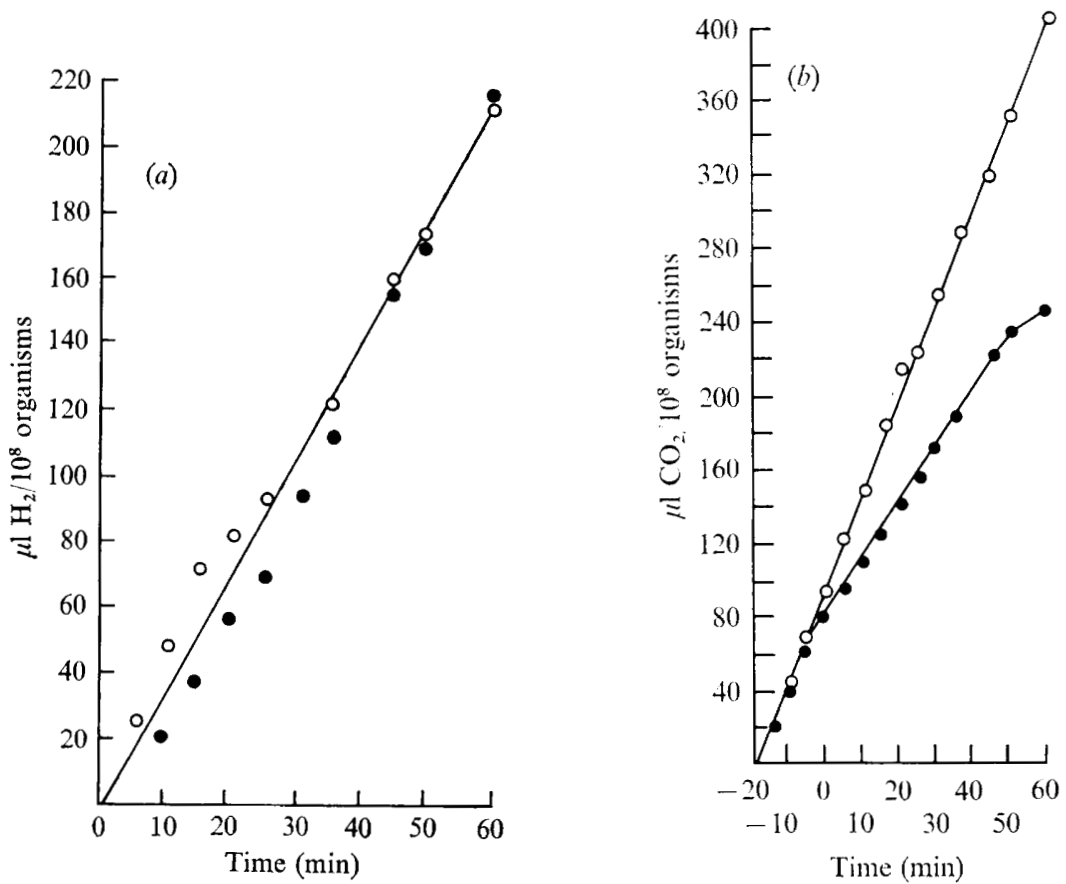

Fig. 6. The effect of nitrofurazone on gas evolution by Clostridium welchii. (a) Effect on $\mathbf{H}_{2}$ evolution. Details as for Fig. $3(a)$ except that the side arm contained nitrofurazone to give a final concentration of $100 \mu \mathrm{g} / \mathrm{ml}$. Drug was added at o min. $\mathrm{O}-\mathrm{O}, \mathrm{H}_{2}$ evolution in absence of nitrofurazone; -, $\mathrm{H}_{2}$ evolution in presence of nitrofurazone. (b) Effect on $\mathrm{CO}_{2}$ evolution. Details as for $(a)$. 

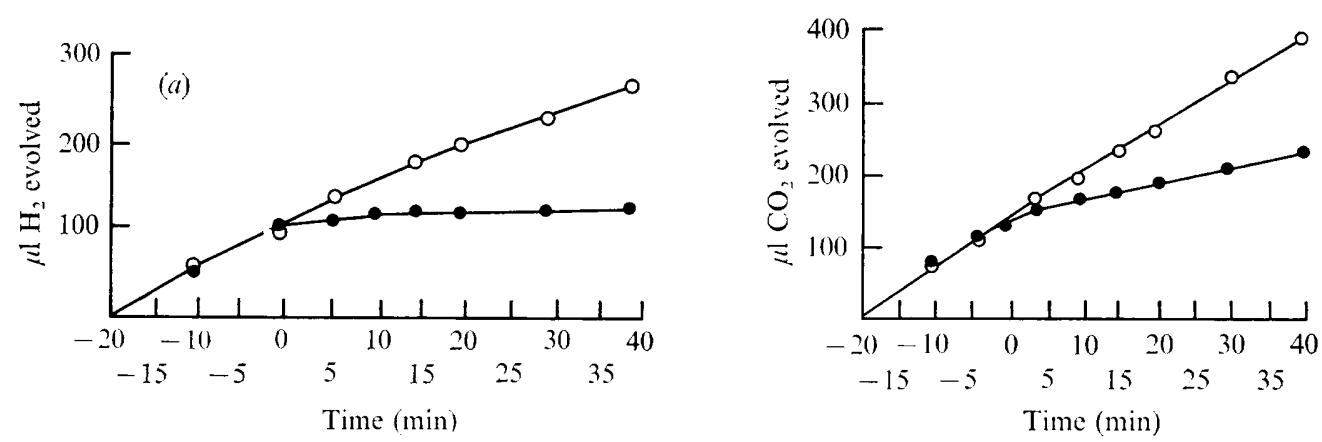

Fig. 7. Effect of dimetridazole on gas evolution by Trichomonas vaginalis. (a) Effect on $\mathrm{H}_{2}$ evolution. The main flask contained $2 \mathrm{ml}$ of a suspension $\left(5 \times 10^{7}\right.$ organisms $\left./ \mathrm{ml}\right)$ in Bushby's medium. The side arm contained either drug to give a final concentration of $200 \mu \mathrm{g} / \mathrm{ml}$ or medium only. Drug was added at $\mathrm{o}$ min. $\mathrm{O}-\mathrm{O}, \mathrm{H}_{2}$ evolution in absence of dimetridazole; $-\mathrm{O}, \mathrm{H}_{2}$ evolution in presence of dimetridazole. (b) Effect on $\mathrm{CO}_{2}$ evolution. Details as for $(a)$.
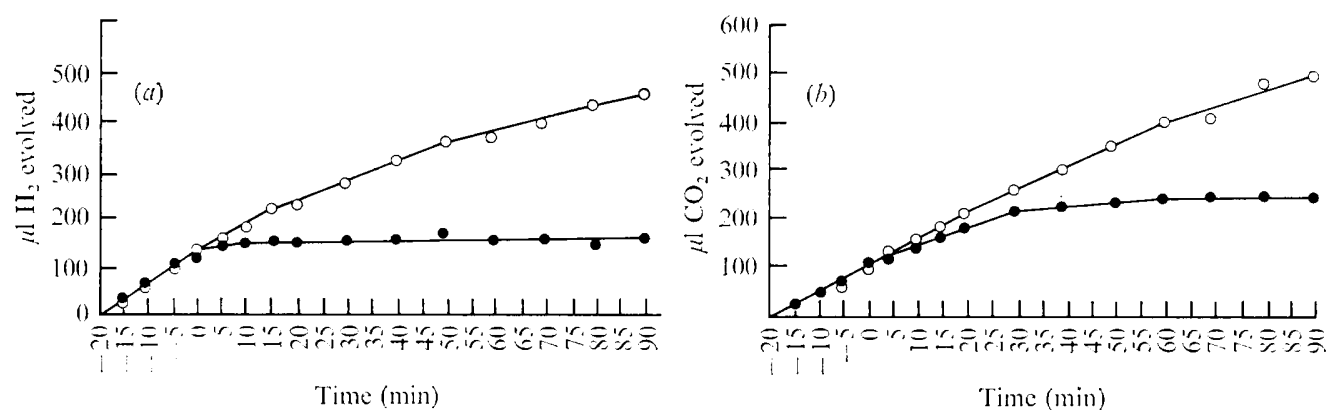

Fig. 8. Effect of tinidazole on gas evolution by Trichomonas vaginalis. (a) Effect on $\mathrm{H}_{2}$ evolution. Details as for Fig. $7(a)$ except that the side arm contained tinidazole to give a final concentration of $200 \mu \mathrm{g} / \mathrm{ml}$. Drug was added at $\mathrm{O} \mathrm{min}$. $\mathrm{O}-\mathrm{O}, \mathrm{H}_{2}$ evolution in absence of tinidazole; $-\mathbf{O}, \mathrm{H}_{2}$ evolution in presence of tinidazole. (b) Effect on $\mathrm{CO}_{2}$ evolution. Details as for $(a)$.

nitrofurazone, shows an interesting difference (Fig. 6). The effect of metronidazole on gas evolution in Trichomonas vaginalis (Edwards \& Mathison, 1970) is very similar to that produced by dimetridazole (Fig. 7) and tinidazole (Fig. 8).

The three nitroimidazoles have a similar action on Clostridium welchii in that evolution of hydrogen is inhibited before that of carbon dioxide. In fact, dimetridazole and tinidazole have little effect on $\mathrm{CO}_{2}$ production (Fig. $4 b, 5 b$ ) at the concentration used, but show the inhibitory effect at higher concentration against Trichomonas vaginalis (Fig. 7, 8).

The pattern of inhibition is, however, reversed in the case of the nitrofurazone, which has virtually no effect on $\mathrm{H}_{2}$ production but inhibits $\mathrm{CO}_{2}$ production; this effect is contrary to the observation of Wolfe \& O'Kane (I953) that $\mathrm{H}_{2}$ evolution was inhibited and $\mathrm{CO}_{2}$ evolution was stimulated in Clostridium butyricum which is far more sensitive to the drug (m.i.c. $6 \cdot 4 \mu \mathrm{g} / \mathrm{ml}$ ) than C. welchii (m.i.c. $25 \mu \mathrm{g} / \mathrm{ml}$ ). It does indicate, however, that the nitrofurans may have a different mode of action from the nitroimidazoles.

If the nitroimidazoles and nitrofurazone act as electron acceptors it may be expected that there would be an accumulation of hydrogen ions within the organism if the ring was reduced, but not if the nitro group was reduced. To test this hypothesis the effect of the three nitroimidazoles on the $\mathrm{pH}$ of an organism suspension in $0.85 \%(\mathrm{w} / \mathrm{v})$ sodium chloride 
solution was investigated. At $200 \mu \mathrm{g} / \mathrm{ml}$ the drugs had no effect on the $\mathrm{pH}$ of a suspension of $10^{8}$ Clostridium welchii organisms/ml, nor had metronidazole any effect on the $\mathrm{pH}$ of a suspension of Trichomonas vaginalis, which indicates that the drugs do not cause hydrogenion accumulation. It can, however, be shown that 5-nitroimidazoles accept electrons via the nitro group. Firstly, metronidazole can be measured polarographically, and reduced metronidazole (i.e. I- $\beta$-hydroxyethyl-2-methyl-5-aminoimidazole) gives no polarographic wave. More direct evidence comes from spectrophotometric measurements on metronidazole reduced by dithionite. Metronidazole ( $234 \mathrm{nmol}$ in $2.5 \mathrm{ml} 20 \mathrm{~mm}$-potassium phosphate buffer, $\mathrm{pH} 7 \cdot 5)$ was reduced by sodium dithionite $(265 \mathrm{nmol})$ in the anaerobic cuvette. This resulted in a decreased extinction at $319 \mathrm{~nm}$ from 0.900 to 0.360 . Since all the dithionite has been oxidized (metronidazole is in excess) one molecule of the drug must be reduced by $265 / 234 \times 0.9 / 0.54=\mathrm{I} \cdot 9$ molecule of dithionite. This is compatible with a 2 -electron reduction mechanism. Shaking the reaction mixture in air gave no increase in $E_{319}$, indicating that the reduction of the nitro group was essentially an irreversible process; this has been corroborated by polarographic studies which indicate that the electrochemical reduction is not a reversible process (D. I. Edwards \& M. J. Parnell, unpublished results).

These results are compatible with the work of Hoffman (I953) and Rabinowitz \& Pincer (1956), who found that reduced nitroimidazoles are unstable and cause fission of the heterocyclic ring to amino acid derivatives. The fact that no increase in $E_{319}$ occurred indicates that the ring is irreversibly cleaved.

The reduction of the nitro group in contact with Clostridium welchii was similarly demonstrated with metronidazole by measuring $E_{319}$. Metronidazole $(200 \mu \mathrm{g} / \mathrm{ml}$ final concentration) was added to an actively gassing culture of Clostridium welchii containing $5 \times 10^{8}$ organisms/ $\mathrm{ml}$ and incubated anaerobically at $37^{\circ} \mathrm{C}$ for $2 \mathrm{~h}$. The organisms were removed by centrifuging at $10000 \mathrm{~g}$ for $30 \mathrm{~min}$ and the supernatant diluted 25 times. $E_{319}$ of the supernatant was 0.55 . The extinction of a culture supernatant in which the drug was absent, but treated in the same way, was $0.5 \mathrm{I}$. Since the addition of $4 \mu \mathrm{g}$ metronidazole $/ \mathrm{ml}$ to diluting medium produced an

increase in $E_{319}$ of 0.18 , there was only approximately $0.9 \mu \mathrm{g} \mathrm{drug} / \mathrm{ml}$ remaining in the diluted culture supernatant or approximately $22.5 \mu \mathrm{g} / \mathrm{ml}$ in the original culture, indicating approximately $89 \%$ reduction of metronidazole. That the decrease in $E_{319}$ was due to reductive ring fission was supported by the observation that dithionite added to the culture supernatant produced a further decrease in $E_{319}$ from 0.55 to 0.50 , a process which was not reversible by shaking in air.

\section{DISCUSSION}

The action of the three 5-nitroimidazoles, metronidazole, dimetridazole and tinidazole are similar in that all selectively inhibit $\mathrm{H}_{2}$ production from both Clostridium welchii and Trichomonas vaginalis. It has already been established that metronidazole exerts its effect on the hydrogenase component of a clostridial-type phosphoroclastic system in $T$. vaginalis, and the evidence obtained in this study indicates that the other nitroimidazoles, dimetridazole and tinidazole also act as electron acceptors in the clostridial phosphoroclastic reaction. Any valid theory as to the mechanism of action of these drugs must take into account the fact that (i) all susceptible organisms are anaerobic or micro-aerophilic; (ii) all active compounds contain an indispensible nitro group; and (iii) reduction of the nitro group abolishes activity.

Hydrogen evolution in micro-organisms is intimately linked with electron transfer mechanisms (Gest, 1954), and in both clostridia and Trichomonas vaginalis hydrogen is produced by a pyruvate phosphoroclastic reaction (Fig. 9). The key sequences in this reaction 


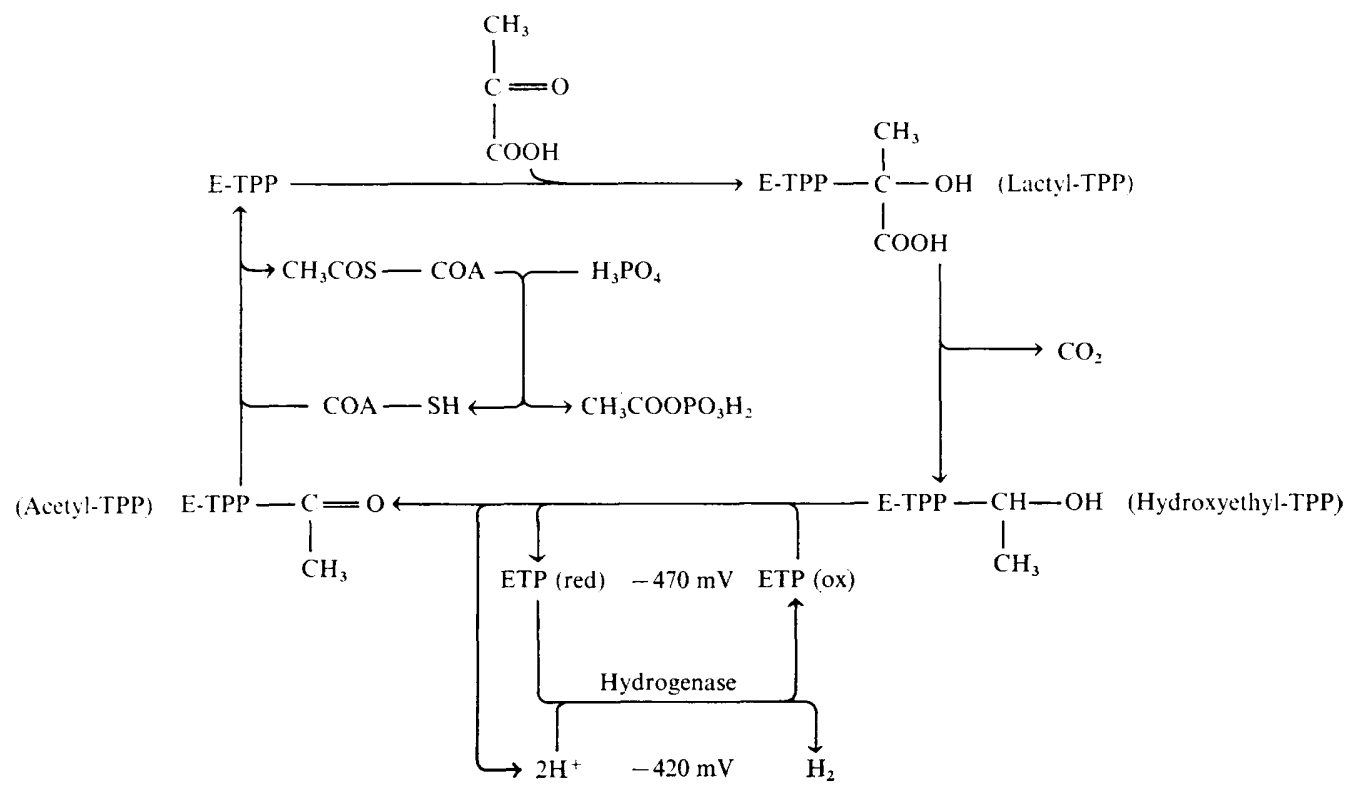

Fig. 9. The pyruvate phosphoroclastic reaction. All reactions are carried out bound to an enzymethiamine pyrophosphate complex (E-TPP). ETP is an electron transfer protein which is normally ferredoxin in clostridia. The redox potentials given are for ferredoxin $(-470 \mathrm{mV})$ and the hydrogen electrode (hydrogenase system) $(-420 \mathrm{mV})$. Active 5-nitroimidazole drugs act by irreversibly accepting electrons from reduced ETP thereby inhibiting $\mathrm{H}_{2}$ evolution.

complex are the reduction of the electron transfer protein, which is of unknown structure in $T$. vaginalis but is ferredoxin in clostridia (Mortenson, Valentine \& Carnahan, 1962; Mortenson, 1963), and the transfer of electrons from reduced ferredoxin to the hydrogenase enzyme to produce hydrogen gas. It is significant that the phosphoroclastic reaction and $\mathrm{H}_{2}$ evolution are found only in anaerobes or micro-aerophiles, and that the redox potentials of the ferredoxin and hydrogenase systems are $-470 \mathrm{mV}$ and $-420 \mathrm{mV}$ respectively. Redox reactions of this potential are not encountered in aerobic microbial systems (photosynthesis excepted).

It is not unreasonable to suppose then that 5-nitroimidazoles act by accepting electrons from reduced ferredoxin via the nitro group, becoming irreversibly reduced in the process. This theory is supported by the facts that the drugs are reduced in contact with Trichomonas vaginalis and Clostridium welchii, and that the reduction is a 2-electron process. The interesting feature is the relative inactivity of 5-nitropyrazole (M \& B 4998), and 4-nitroimidazole ( $8609 \mathrm{RP})$, and the totally different effect of the nitrofuran, which can be explained by the relative redox potentials of the compounds and those of the ferredoxin and hydrogenase systems. The redox potentials of the 5-nitroimidazoles cannot be measured accurately as the reduction process is an irreversible one. Instead the polarographic half-wave reduction potential $\left(\epsilon \frac{1}{2}\right)$ is measured, which approximates to the redox potential of a reversible system. Metronidazole and dimetridazole have $\epsilon \frac{1}{2}$ values of $-415 \mathrm{mV}( \pm 30 \mathrm{mV})$ and $-440 \mathrm{mV}$ $( \pm 30 \mathrm{mV})$, potentials thermodynamically compatible with those of the ferredoxin and hydrogenase systems $(-470$ and $-420 \mathrm{mV}$ respectively). Since both metronidazole and dimetridazole have less negative reduction potentials than ferredoxin the drugs can accept electrons from the protein, both the nitro group and the imidazole ring conferring the properties of an 
efficient electron sink on the drugs. The fact that 8609 RP and M \& B 4998 are relatively inactive is explained by their $\epsilon \frac{1}{2}$ values of $-6 \mathrm{IO}( \pm 30)$ and $-635 \mathrm{mV}( \pm 30 \mathrm{mV})$ respectively, which are too negative to act as efficient electron acceptors.

The action of nitrofurazone is certainly not the same as the 5-nitroimidazoles; inhibition of $\mathrm{CO}_{2}$ evolution before that of hydrogen suggests that its site of action may involve the decarboxylation step of the phosphoroclastic system, as well as $\mathrm{H}_{2}$ evolution, although nitrofurans are reduced by sensitive cells. This observation substantiates the work of McCalla, Reuvers \& Kaiser (1970), who found that reduced nitrofurazone becomes irreversibly bound to protein, and can also cause damage to DNA (McCalla, Reuvers \& Kaiser, 197I).

The function of the 5-nitroimidazoles as electron-acceptors, although being their primary site of action, may not represent their primary mode of action as antimicrobial agents. There remains the interesting possibility that, like nitrofurans, the reduced nitroimidazoles may bind to proteins, and these breakdown products may be the agents lethal to the cell. The spectrum of activity and selective toxicity of the 5-nitroimidazoles are explained by the fact that only anaerobes have redox systems of such negative potentials with which the drugs can interact.

It is also evident that the key feature of active compounds is the position of the nitro group (4-nitro compounds are less active or inactive). The nature of the r-substituent, then, determines the degree of ionization of the nitro group, and also the solubility. This interpretation explains the studies of Miller et al. (I970) and Howes, Lynch \& Kivlin (1970), who found that electronegative substituents in the side chain in the I-position increased activity of nitroimidazole.

We would like to thank M. J. Parnell, L.R.I.C., of the Applied Physical Chemistry Laboratories, May and Baker Ltd, for providing the polarographic analyses, and May and Baker Ltd, Dagenham, Essex, for providing metronidazole, dimetridazole, M \& B 4998, and 8609 RP, Pfizers Ltd, Sandwich, Kent, for providing tinidazole, and Smith, Kline and French for providing nitrofurazone.

\section{REFERENCES}

Asnis, R. E., Cohen, F. B. \& Gots, J. S. (1952). Studies on bacterial resistance to Furacin. Antibiotics and Chemotherapy 2, I23-I 30.

Bushby, S. R. M. \& Copp, F. C. (1955). The antitrichomonal activity of amido-nitrothiazoles. Journal of Pharmacy and Pharmacology 7, II2-I 17.

Cosar, C. \& Julou, L. (1959). Activité de l'(hydroxy-2-ethyl)-l-methyl-2-nitro-5-imidazole (8.823 R.P.) vis-à-vis des infections experimentales à Trichomonas vaginalis. Annales de l'Institut Pasteur 96, 238-24I .

Edwards, D. I. \& Mathison, G. E. (1970). The mode of action of metronidazole against Trichomonas vaginalis. Journal of General Microbiology 63, 297-302.

Edwards, D. I. \& Mathison, G. E. (1973). Metronidazole: an antimicrobial drug which inhibits photosynthesis. Zeitschrift für Pflanzenphysiologie (in the press).

Edwards, D. I. \& Schoolar, A. I. (I97I). Inhibition of sugar synthesis and potentiation of chlorophyll degradation in sugar cane leaf tissue by metronidazole. Zeitschrift für Pflanzenphysiologie 64, 73-76.

Felix, H. \& Ouryoux, C. (1962). Traitement de la lambliase par le Metronidazole. Presse Médicale 7o (26), I32I.

Freeman, W. A., McFadzean, J. A. \& Whelan, J. P. F. (1968). Activity of metronidazole against experimental tetanus and gas gangrene. Journal of Applied Bacteriology 3I, 443-447.

Fuzı, M. \& Czukas, Z. (1970). Das antibakterielle Wirkungspektrum des Metronidazols. Zentralblatt für Bakteriologie, Parasitenkunde, Infektionskrankheiten und Hygiene (Abteilung I) 213, 258-262.

GeST, H. (1954). Oxidation and evolution of molecular hydrogen by micro-organisms. Bacteriological Reviews I8, 43-73.

Hoffman, K. (I953). In The Chemistry of Heterocyclic Compounds, vol. vi, part I. Edited by W. Weissberger. 
Howes, H. L., LynCH, J. E. \& Kivlin, J. L. (1970). Tinidazole - a new antiprotozoal agent: effect on trichomonas and other protozoa. Antimicrobial Agents and Chemotherapy, 26I-266.

LUCAS, J. M. S. (196I). I,2-dimethyl-5-nitroimidazole, 8595 R.P. I. Prophylactic activity against experimental histomoniasis in turkeys. Veterinary Record 73, 465-7.

McCalla, D. R., Reuvers, A. \& Kaiser, C. (I970). Mode of action of nitrofurazone. Journal of Bacteriology I04, I I 26-I I 34.

McCalla, D. R., Reuvers, A. \& Kaiser, C. (1971). Breakage of bacterial DNA by nitrofuran derivatives. Cancer Research 3I, 2184-2188.

Miles, A. A. \& MisRa, S. S. (1938). The estimation of the bactericidal power of the blood. Journal of Hygiene 38, $732-749$.

Miller, M. W., Howes, H. L. \& English, A. R. (1970). Tinidazole - a potent new antiprotozoal agent. Antimicrobial Agents and Chemotherapy, 257-260.

Mortenson, L. E., Valentine, R. C. \& Carnahan, J. C. (1962). An electron transfer factor from Clostridium pasteurianum. Biochemical and Biophysical Research Communications 7, 448-452.

Mortenson, L. E. (I963). Nitrogen fixation: role of ferredoxin in anaerobic metabolism. Annual Reviews of Microbiology 17, I1 5-138.

Paul, H. E. \& Paul, M. F. (1964). The nitrofurans - chemotherapeutic properties. In Experimental Chemotherapy, vol. 2, pp. 307-370. Edited by R. J. Schnitzer and F. Hawking.

Powell, S. J., McLeod, I., Wilmot, A. J. \& Elsdon-Drew, R. (I966). Metronidazole in amoebic dysentery and hepatic liver abscess. Lancet ii, I329-I33I.

Rabinowitz, J. C. \& Pincer, W. E. (1956). Purine fermentation by Clostridium cylindrosporum. Journal of Biological Chemistry 222, 537-554.

Thornley, J. \& EDWARDS, D. I. (1973). Treatment of an unusual case of gas gangrene by metronidazole. Canadian Journal of Medicine (in the press).

Umbreit, W. W., Burris, R. H. \& Stauffer, J. F. (1964). Manometric Techniques. Minneapolis: Burgess Publishing Co.

Wolfe, R. S. \& O'Kane, D. J. (1953). Co-factors of the phosphoroclastic reaction of Clostridium butyricum. Journal of Biological Chemistry 205, 755-765. 